\title{
THE REDEFINITION OF REGIONAL SECURITY: THE RISE OF THE KRI AS A NON-DISPENSABLE PARTNER
}

\author{
SARDAR SHARIF \\ Dept. of Public Policy, College Of Humanities, University of Duhok, Kurdistan Region-Iraq
}

(Received:January 14, 2021; Accepted for Publication: February 21, 2021)

\begin{abstract}
ABSRACT
Recent developments in the Middle East and North Africa (MENA), such as the Arab Spring and the emergence of ISIS, have increased insecurity and political instability in the region. Apropos the autonomous Kurdistan Region of Iraq (KRI), the area's active participation in the war against ISIS has repositioned the KRI as a valuable actor and raised its status internationally. The assertive diplomacy on both the regional and global stage practiced by the KRI has reshaped the region by locating it in a key position in the war on terror. Furthermore, international support for the KRI in its fight against ISIS has further pushed its ambition toward independent statehood. The indigenization of KRI diplomacy in the war on ISIS and the role played by the KRI as covered by the media since August 2014 has solidified its regional and international position. Furthermore, the decision of the independence referendum and its outcomes have seemingly provided a more comfortable position for the KRI to balance power in the region.
\end{abstract}

KEYWORDS: KRI, Sub-State, Diplomacy, Military, Security

\section{INTRODUCTION}

$\mathbf{T}$ The Iraqi Constitution of 2005 laid the foundations of the Iraqi state, including recognition of the Kurdistan Region of Iraq (KRI). In the first paragraph of Article 117, the constitution underscores the need to "recognize the region of Kurdistan, along with its existing authorities, as a federal region". Additionally, Article 141 draws attention to the politically recognized status of the KRI and further stresses the power the region has exercised since 1992, stipulating that "legislation, decision, court decision, and contracts... since 1992 shall remain in force ... shall be considered valid... provided that they do not contradict with the Constitution" of 2005 (Iraq's Constitution of 2005). Based on the constitution, the legal forms for progress in Iraq towards a multi-ethnic, multi-national, and socio-political society have been structured. From an academic and political perspective, such states intellectually challenge numerous International Relations (IR) approaches mainly state-centric ones, particularly sub-state units that act more independently from the mother state. Also, those actors tend to have political rather than economic agendas, which they use to attempt socialization within the international community to market their values and national interests and objectives. Besides political and economic subjects, such actors have dominated both regional and global security matters
(Cornago, 1999). Such an issue often relates to serious threats, making certain actors indispensable partners for sovereign states, actors that are capable of contributing to domestic and regional security. In general, nonstate actors have to be divided into categories such as armed or non-armed, legitimated political statues, or illegitimate and unrecognized political organizations, which is not the central objective of this research.

Related to the above-mentioned picture, for instance in the war against ISIS, the KRI utilises a defence force known as the Peshmerga, a boots-on-the-ground military response to the threat of ISIS. This has been supplemented by international coalitions that provide air support, a crucial instrument in the success of the Peshmerga forces. This new trend in international and regional security, as well as the cooperation between sub-state units and sovereign states, has shed light on new forms of alliance concerning collective security within a regional and international security context. Also, as an exceptional example, the KRI - with its legal status as a sub-state unit - has been able to play a crucial role in what has been labelled collective security. Therefore, based on such a view, the KRI's interaction with the international community challenges the traditional statecentric approach in analysing international politics. Such practices shed light on the transformation of international relations and 
diplomacy toward more complex relations, even if a new environment of socialization as an argument has been structured for normalization of sub-state units to enter into an alliance and building partnerships with other regional and international communities (Barton, 2018; Martin \& Kozak, 2016).

Certainly, such changes raise questions about accommodation of sub-state units within the structure of international and regional politics, and also a change in diplomatic statecraft. In simple terms, such a structure deliberates the nature of the relation between the state and its milieu, where the environment appears as a generative power that forces, controls, and regulates state behaviour (International Crisis Group, 2019). As a sub-state actor, the KRI is geopolitically sandwiched between adversaries that frame the KRI as a serious threat to their territorial sovereignty and national security, despite such facts in the ground within the postSaddam era in Iraq. Such adversaries could hardly neglect the importance of the KRI's position in their political and security calculations within the context of Middle Eastern politics (Dalay, 2016; Dalay, 2015). In simple terms, the KRI's relations with the Iraqi Government, regional actors (e.g., Turkey and Iran), and global superpowers (e.g., the United States, France, and Russia) are the best examples that illuminate the autonomous region's significance and exceptional case as a sub-state unit of global relevance (O'Leary, 2017). Provided by Kawa Hassan from the East-West Institute, the domestic boundaries have been concluded as a political system in Iraq, which has created significant opportunities for the KRI, including to act as a legitimate participant. Yet despite such positive opportunities, the KRI faces extensive threats both externally and domestically.

Current conflicts $\mathrm{f}$. instance war against ISIS have moved into a new juncture of political power clashes between stakeholders, including global superpowers, regional states, and local actors, which points to the dismantling of state power authority. Such conflicts also indicate the necessity of projecting some kind of prosperous security strategies for the future of the Middle East, ones that aim to establish regional order and stability (Cordesman, 2016). Using the war against ISIS, the referendum, and the postreferendum environment to analyse the KRI within the context of the regional political system constitutes several elements that have changed the KRI's behaviour. Further, the behaviours of the KRI are shaped by the balance of power and balance of relations between different actors often influenced by the KRI's domestic political structure, as well as Iraq's Shi'a dominated politics (which exclude Sunnis), and the Middle East political context, influenced by the Arab Spring and the subsequent emergence of ISIS. In effect, based on current regional and global conflicts, the argument is that states as sovereign actors should not ignore the role played by non-state actors due to the nature of conflicts. In short, such perception proposed by Sardar Aziz accentuates that "twenty-first-century conflicts make local partners necessary", yet this sheds light on the change that has occurred within international legal norms, in which supportive states become more dependent on indigenous collaborators and alternatives, a situation that does not seem likely to disappear in the near future (Aziz, 2019).

Through a descriptive framework, this research positions the KRI as a unitary rational security actor and proposes as its central hypothesis that the war on ISIS has empowered the KRI's regional and international positions, while the second hypothesis emphasizes that the outcomes of the referendum have regulated the KRI's regional and international behaviour. By exploring the current KRI political and security environment, influenced by the war against ISIS that in turn has shaped the KRI's role as a security actor, the research attempts to respond to the raised hypotheses. The first section attempts to deliver an emerging recognition of sub-state actors' role in international and regional security matters and their impact on political outcomes. The second section provides a picture of a failed strategy by sub-state actors in achieving sovereign status but also how the political structure on the regional and international system applies international norms to defend their security. The third section shed lights on the role of sub-state units' military forces and their interaction with the international defence community as a valuable actor. Finally, the conclusion draws an overall perspective about the future of the KRI and its position regionally.

\section{KRI-USA Relations: Trapped between the Baghdad-Tehran Axis}

In 2014, John Kerry became the first U.S. Secretary of State since 2006 to visit the KRI, with the aim of convincing Kurdish decisionmakers to join the formation of a new 
government in Baghdad. Kerry highlighted the fragile nature of Iraq as a factor that contributed to regional instability, and in his meeting with the KRI President, Masoud Barzani, Kerry acknowledged the region's important position within the context of Iraqi politics and also the role the KRI can play in the international network against ISIS, thus assigning more political credibility to the KRI. But to avoid negative consequence he urged Kurds to not "withdraw from the Baghdad political process "but for Kurds being part of the political process in Baghdad simply has been tragic argues KRI president (Kurds to Kerry: We Are Facing A 'New Iraq', June 24, 2014).

The current power vacuum in Iraq is significant for the United States to exert its efforts to reduce the pressure it now faces, which puts the United States in a position to balance the pressure exerted by Baghdad and Shi'a militia groups. The assassination of General Qassem Soleimani created both political and diplomatic conflict between Iraq's Shi'adominated government from one side and militia groups with the USA. Therefore, in response to USA action, Iraqi Shia groups such as Kataib Hezbollah and Al-Tofof Brigades that are known as Iranian proxies groups and also Iran by undertook an attack on the Ain al-Asad airbase, the Besmaya base, Camp Taji, and the U.S. embassy in Baghdad by missiles. In effect, the Chief Pentagon Spokesperson at the time, Jonathan Hoffman, and the then-Defense Secretary Mark Esper reiterated that the United States "will hold them accountable" (Caggins III, 2020, Abdul-Zahra \& Kullab, 2020). Most importantly, harsh rhetoric was employed by Prime Minister Adil Abd Al-Mahdi, who accused the United States of killing the "Symbols" of victory in the war against Daesh about Soleimani, as well as Abu Mahdi alMuhandis (Lee, 2019). In this regard, legal documents initiated by Shi'a groups represented in the Iraqi parliament on 5 January 2020 were passed to force and obligate Al-Mahdi's government with the request of expelling foreign troops especially the USA military presence in Iraq. Above all, this situated Al-Mahdi in a dangerous position, trapped between Tehran and Washington, but it was more a power demonstration by the United States's adversaries. In contrast, visualizing active popular demonstrations in Shi'a-dominated governorates, it is important to shed light on one of the key demands of demonstrators, which is to return sovereignty to Iraq. The demand is a reference to Iranian hegemony in Iraq, and demonstrators have shown their anger by burning Iranian diplomatic representations, including consulates and pictures of Iranian symbols that have decorated most Iraqi cities and public spheres, as well as publicly demanding the expulsion of Iran from Iraq (Iraq protests: All the latest updates, Oct 11, 2019).

Such circumstances have become a real test for the elaboration of the nature of KRI-USA relations. In broader terms, the resolution adopted by the parliament is solely a Shi'a majority decision. As for the KRI's position on such resolution, the region's President, Nechirvan Barzani, has accentuated that neither Kurds nor Sunnis were involved in reaching such a conclusion, and so Shi'a behaviour and their consequent decisions are not accepted (Mustafa, 2020; Beaumont, 2020; Government of Iraq, 2020; Ibrahim, 2020; Zaman, 2020; Pollock, 2020). In short, Barzani's statement points to the increasing concerns among Kurds and also Sunnis apropos the ongoing political development in Iraq. Further, instrumentalizing a Shi'a majority in parliament is a direct attempt to impose Shi'a preferences and will on both the Kurds and Sunnis, framed within the context of protecting Iraq's national interests.

In the foreground, when Donald Trump became President of the United States in 2017, the KRI was one of the first actors in the region to receive a phone call from Vice-President Mike Pence, as a gesture toward KRI leadership and to send a political message that the United States values their mutual relations (Ali, 2016). Recently, in a similar manner, Pence conveyed U.S. anxiety to President Barzani apropos Iranian behaviour in Iraq, which has destabilized the country and undermined its sovereignty. Moreover, Pence highlighted that the United States remains determined to take decisive action against Iranian proxy groups to reduce their influence in Iraq, and re-emphasized the United States's determination to work with the KRI "to bring stability to the disputed territories" and establish a secure environment for ethnic minorities to return to their home (Readout of Vice President Mike Pence's Call with Iraqi Kurdistan Region President Nechirvan Barzani, Aug. 27, 2019). In 2020, U.S. Secretary of State Mike Pompeo, in a phone conversation with KRI Prime Minister Masrour Barzani, signalled the durable and solid relations between both actors, characterized by Pompeo as a 
"steadfast partnership" and a mutual agreement, emphasised by what he referred to as a continuation of the "close cooperation" between the KRI and the United States (U.S. Department of State, 2020). Others have argued that U.S. policy in Iraq has to be revised as "the time when we had good, easy answers for the problems of Iraq are long gone" (Pollack, 2015). Based on what they (decision-makers) are witnessing, it might be much more comfortable to say goodbye to the "one policy" towards Iraq proposed by Kenneth Pollack, Senior Fellow at the Center for Middle East Policy of the Brookings Institution (Pollack, 2015). Pollack mentions the KRI as a durable and solid ally of the United States in Iraq and states that the latter must include the autonomous region's political demands within its Iraq policy.

On the contrary, at the Middle East regional level, Iran was one of the first countries to assist the KRI in combating ISIS, through the provision of military aid. In short, Iran used such an event perfectly, first to deepen its relationship with the KRI, and second, to gain political leverage by not hesitating to dispatch the Speaker of the Iranian parliament, Ali Larijani, as one of the top Iranian officials to visit Erbil. Politically and diplomatically, the Iranian visit made a significant impression on the Kurds, despite the rupture between Iran and the Kurdistan Regional Government (KRG) of Iran, which values its historical relations. Further, the ISIS threat against the KRI emerged in June 2014 as a new rapprochement in Erbil-Tehran relations (Sinkaya, 2014).

In the meantime, the KRG prime minister, Nechirvan Barzani, visited Tehran on 16 June 2014 and met with Iranian security officials, particularly Ali Shamkhani, Head of Iran's National Security Council (Iraqi Kurdistan PM in Iran for talks, 06 June 2014). In early August of that same year, Masoud Barzani, then President of the KRI, penned a dispatch addressing Iranian President Hassan Rouhani, thanking him for the aid provided by Iran to the Kurdistan Region. In brief, ISIS and the increase of its threat not only guided the revival of security cooperation between Erbil and Tehran but also energized political relations between the two factors. As an illustration, Iranian Foreign Minister Mohammad Javad Zarif paid the first high-level official to visit Erbil on 26 August, shortly after Zarif visited the region, and Ali Larijani, Speaker of the Iranian Parliament visited Erbil in December 2014. KRI President
Masoud Barzani described Larijani's visit as the beginning of a new phase in the relations between Iran and the KRG (Sinkaya, 2015).

Additionally, the last three decades of the KRI-USA interaction underscores an improvement and development of such relations into much stronger and institutionalized relations. Since 1991, the United States' roles have progressed towards a more alliancebuilding nature, for instance, the role played by the nation in protecting the current KRI from Saddam Hussein's attacks, and the latter region's subsequent progress into an institutionalized body within the Iraqi constitution is evident. Additionally, the United States has also worked as a mediator to secure peace between the Kurdistan Democratic Party (KDP) and the Patriotic Union of Kurdistan (PUK) during the civil war, which concluded with the Washington agreement in 1998. The key role the United States played in the unification of the KRG administration has increased and solidified, and Kurds have got many friends within the U.S. establishment, with the regular diplomatic, military, and cultural meetings between the two sides strengthening such relations.

In sum, the ISIS attack on the KRI transported the latter into the international spotlight, which provided the region with the power to gather international support to assist the KRI in its fight against a radical terrorist group. Additionally, a factor that has to be mentioned is the positive covering provided by regional and western media networks, which presented the KRI as an open, tolerant, and prowestern society. These are some of the most influential factors that have had a significant impact on the internationalization of the KRI. Erbil witnessed a diplomatic highway, where state leaders from the West as well as military personnel periodically paid visits to the Kurdistan Region. To illustrate the presented point of argument, from the first ISIS attack on the Kurdistan Region in 2014, a total of 91 international diplomats visited the KRI, including presidents, first ministers, military officials, ambassadors, consulates, and special envoys, all of whom were received by the President of the Kurdistan Region (www.krg.org). ${ }^{1}$

\footnotetext{
1 www.krp.org [2014: Aug-14, Sep. - 4, Oct. - 3, Nov. - 9, Dec. -3, 2015: Jan. -4, Feb. -9, March -7, Apr. -6, May -13, June - 5,July-11, Aug. -4. = Total Visit=91.]
} 


\section{Referendum Diplomacy}

On 25 September 2017, the KRI Independence Referendum took place, presented and advocated by the KRI's president, Masoud Barzani. At the same time, the KDP leader was one of the serious variables related to the elaboration of the KRI as a political actor within the context of Middle East politics in an era of insecurity. In the political context of such a decision, there was not a full consensus regarding such subjects internationally, regionally, or domestically. First, there was a lack of coherent political vision and strategy among the KRI's stakeholders (e.g., the KDP, PUK, Goran, and Islamic parties), where such a factor, as mentioned before, is under the strong influence of regional actors. Second, it was alleged that the KDP and its leadership used the subject of the referendum as a feature of their domestic political purposes. These challenges were intentionally designed to put maximum pressure on Barzani and the KDP, which underscores the strategy that was implemented. Third, all KRI political parties supported the referendum and the rights of Kurds to vote for an independent Kurdistan. To be sure, political parties demanded that the KRG as well as the KDP, which held a powerful ministerial position within the former administration, address real political issues faced by the KRI. For instance, the demands included ensuring that "apolitical solution to political and economic challenges [is] closely followed by social equality and the unity of political actors" (Salih, 2015).

The issue placed extreme pressure on Hayder Al-Abadi, the Iraqi Prime Minister, and Baghdad's position became clear as it perceived the KRI's decision as a violation of its sovereignty. As such, the Iraqi government refused to accept the referendum conclusion and insisted the KRI withdraw from the disputed territory, with the threat that failure to do so would result in forced expulsion. Therefore, in a tactical step supported by Iran and Turkey, Baghdad secretly negotiated with the PUK, and then deployed Shi'a militia groups to the conflicted territory between Iraq and KRI as disruptive elements with the assistance of Iran, resulting in a clash between the KRI's Peshmerga and the Shi'a militia. Ultimately, Baghdad seized control of the disputed territory (extending from Sinjar to Khanaqin) and brought the oil-rich city of Kirkuk under its control (Zucchino, 2016; Wintour, 2017; Aljazeera.com, 2017). Thus, Baghdad initiated a war with the
KRI, which resulted in the use of U.S. military equipment by the Iraqi army and Shia Militias' groups, which angered U.S. decision-makers, including U.S. Senator John McCain, the chairman of the Senate Armed Services Committee, and also the Pentagon, who warned Iraq to refrain from a further military operation against the KRI (Gould et al., 2017). The referendum outcome, lack of unity between the KDP and the PUK, and a neutral U.S. position created inflexible circumstances for the KRI toward Bagdad. Inevitably, the United States also put the KRI in the hands of its regional adversaries. In sum, this environment created an uncertain, unsure, and distrustful situation that transformed the balance of power in the region (Park et al., 2017; Aziz, 2019; Frantzman, 2019).

David L. Phillips, the author of The Kurdish Spring: A New Map of the Middle East, draws attention to the discreet negotiation regarding the future secession of the KRI from Iraq toward independence with affirmative effects. Also, a policy of protection seems to be necessary concerning the present and future of KRI from Western powers mainly the USA makes it possible for Kurds in KRI in the future to declare their independence from Iraq (Kent, 2015). Closely related to regional actors' approach and their role in the current and future state of the KRI, Iranian scholar Nader Entessar brings Tehran's attitude and view towards the KRI into the picture, where the latter remains a valued contributor to stability in Iran. However, it is important for Iran that the KRI ensures that it does not violate Iraqi integrity, which will drive undesirable consequences for Iran's national interest, domestically and regionally. Further, it points to Iran's political objectives behind its relationship with the KRI to recede the negative impact of Kurdish demands (Entessar, 2009). Internationally, however, a serious obstacle to Kurdish independence is the consensus of Baghdad, while the UK Parliament's Foreign Affairs Committee, is a remarkable initiative, swept away the "one Iraqi Policy" to open the road for Kurds in seeking either more power from Baghdad or actual independence. The decision has to be evaluated by the KRI decision-makers concerning the consequences of "unilateral declaration", and therefore the British testimony recommends that the case should be negotiated with Baghdad (Kent, 2015).

Despite the harsh environment the KRI faces, in contrast to having a legal position within the Iraqi constitution, the KRI has emerged as a 
recognized actor within the context of Middle East politics and security subjects. That is to say, to keep the KRI in a check and balance position, other regional states must play a role, particularly Iran and Turkey due to their geographical position and presence of a large Kurdish population, which means having ethnic kin relations attempt to influence the KRI's domestic politics. This regional influence and involvement in KRI affairs remain a serious threat to Kurdish unity and political administration, as highlighted by Gary Kent, Director of Labour Friends of Iraq, and the APPG on Kurdistan. In other words, both Iran and Turkey work as disruptive instruments, and their negative involvement has transformed the KRI into an actual separate political administration sandwiched between an "Irancentric and Turko-centric" zone of influence (Kent, 2015). Furthermore, putting KRI decision-makers' differences aside and focusing on forming a united approach towards domestic and regional issues might work in favour of the Kurdish position and enhance the ability of the KRI to become "a game-changer in the Middle East" (Kent, 2015).

\subsection{Post-Referendum Diplomacy}

On the whole, and challenged by Baghdad, Iran, and Turkey, regional repercussions such as a complete embargo on the KRI increased, while the region desperately sought methods to reduce such tremendous pressure. Certainly, the election of Prime Minister Nechirvan Barzani to the position of President of the KRI on 28 May 2019 (Nechirvan Barzani elected president of Iraq's Kurdish region, May 28, 2019) cheered by regional and international actors, gave new optimism to the KRI. Connected to the subject, in 2017 Barzani, while still the Prime Minister, and Qubad Talabani, the Deputy Prime Minister, were invited to Paris by the French president Emmanuel Macron, which initiated broke of the imposed "diplomatic embargo" on the KRI (President Macron in meeting with PM Barzani sets terms of Erbil-Baghdad dialogue, Dec.02, 2017). This step has been received positively by international and regional states, and international support for the KRI increased in the years following, particularly from the United States, which classified the KRI as one of its strong allies in the region. For instance, former U.S. National Security Advisor John Bolton described the KRI as a "steadfast" ally of the United States within the Middle East, further stating that the election of Nechirvan Barzani was "A significant milestone for the KRG" (Bolton, 2019). Similarly, Morgan Ortagous, Spokesperson of the Department of the State, by picturing the historical nature of relations between the United States and the KRG Prime Minister, stated "we enjoyed a close relationship with him... We've worked with him on many important issues, including regional security, economic reform, and repairing relations between the KRG and the Government of Iraq", while further underscoring that the KRI President will remain "a close partner" of the United States (U.S. Department of state, 2019). The above-mentioned policy subjects are matters of importance for the United States, as they highlight the nation's interest in utilizing its political and diplomatic instruments to stabilize Iraq and build close relations with U.S. partners and allies in the region, thus overcoming the major insecurity environment, in this case also the KRI.

Since 1991, the United Kingdom has also been another major actor and supporter of the KRI. Not only did the United Kingdom applaud the presidential election of Nechirvan Barzani, but then UK Prime Minister, Theresa May, used the event to declare that "The UK looks forward to strengthening its relationship with the people of Kurdistan" (UK Prime Minister, 2019). Additionally, Jeremy Hunt, the former Foreign Secretary of the United Kingdom (UK) underscored that the UK had constantly benefited from a close partnership "with Kurdistan", and was determined to back and provide assistance to President Barzani "to build unity and reconciliation in Kurdistan, Iraq and beyond" (Hunt, 2019). Furthermore, the United Kingdom continually seeks to maintain a solid relationship 'with Kurdistan. Above all, Hunt's message conveyed a strategic and political perspective by highlighting "unity and reconciliation in Kurdistan", while pointing to and thus recognising the position and relevance of the KRI in regional political matters. This message has once again been underscored by the British General Console in Erbil, Martyn Warr (Warr, 2019).

On the regional level, Iranian Foreign Minister Mohammad Javad Zarif and Turkish Foreign Minister Mevlüt Çavuşoğlu were the first to congratulate Nechirvan Barzani on his presidential election (FM Zarif Congratulates Barzani on Election as KRG President). Turkey followed up its congratulations to the Kurdish leader during a phone call, during which Barzani expressed a desire to strengthen the bilateral ties 
between the sides further (Çavuşoğlu, 2019). The list of diplomatic messages expanded greatly after these initial congratulations and points to the fact that the KRI, even after the referendum, will retain its position as a valuable actor that can play a unique role in regional political and security issues of relevance to the above-mentioned actors' special and collective interests.

During its fight with ISIS, the KRI has also played a significant role in collective security matters. Unquestionably, although the international community (in this case both superpowers and regional powers) has been reluctant in response to Kurdish choice on a regional level, it is important to address Turkey and Iran as two major and central actors, since before any decision is made their political objectives have to be considered. Certainly, despite the positive and solid economic and security relations between Erbil and Ankara, there are no signs that Turkey will change its stance in the near future, or evaluate its regional position toward the creation of any Kurdish state.

Taking a historical perspective on analysing the current challenges and desire of Kurdish political parties and decision-makers to declare independent Kurdish statehood, one of the vital obstacles is that Kurds have not yet taken advantage of historical events and moments. For that reason, Kurds have been too positive in seeing an opportunity for themselves at the end of the competition, yet they are the ones who have missed such an opportunity. One of the main causes in this regard points to the unhealthy behaviours that have blighted Kurdish political leadership, for instance placing greater focus on negative aspects of domestic power competition, the lack of positive internal communication, prior to the election of Nechirvan Barzani, and the lack of leadership credibility to generate domestic recognition. These domestic issues point to the fact that the political leadership of the KRI has struggled to agree on a consensus strategy. Second, regional actors have possessed enough power and instruments to challenge Kurdish aspirations of statehood. In sum, Kurdish interests are best directed not towards the struggle between regional powers and superpowers, but rather avoiding becoming involved within such competition for one reason, and to be able to act and co-operate with regional and international powers.

\section{Internationalization of Military Forces}

Baghdad's reluctance to provide the KRI with military armaments during the war against ISIS has been condemned by the KRI. Also as U.S. policy is rooted in the practice of the international norms practicing these norms prevent the United States from taking any unconventional action without having sovereign state approval as accentuated by former Spokesperson for the United States Department of State, Jen Psaki the fact is that U.S. law prevents transferal of arms (Saeed, 2015). Also, any transfer of weapons by the USA necessitates for instance Iraq's central Government acceptance. On the other hand, lacking a clear understanding of the Iraqi constitution some see the status of the Peshmerga being unclear, and therefore have no sense in their arguments as their references require a deeper understanding of the Iraqi Constitution of 2005, as argued by Crispin Smith (2018, p. 254). In contrast according to the Constitution, the Peshmerga is a recognized instrument of the Iraqi defence force. In contrast to such argument, the Iraqi constitution in an unambiguous manner recognizes that regions have their own security forces and guards. Apropos the legal position of the Peshmerga forces, the Iraqi constitution has clarified within the context of Article 141 that "Legislation enacted in the region of Kurdistan since 1992 shall remain in force, and decisions issued by the government of the region of Kurdistan, including court decisions and contracts, shall be considered valid unless they are amended or annulled according to the laws of the region of Kurdistan by the competent entity in the region, provided that they do not contradict with the Constitution" (Iraq's Constitution of 2005). Therefore, it is important to connect such an article to the Kurdistan Region Parliament law nr. 5, 1992, which passed the parliament based on the decision of nr. 19, on 1 October 1992. Within such a context, since 1992 domestic power political rivalry among the main stakeholders (e.g., the Kurdistan Democratic Party (KDP) and Patriotic Union of Kurdistan (PUK)) has played a significant role in the institutionalization of such forces into unified national forces. To illustrate, Mustafa Sayid Qadir, former Minister of Peshmerga Affairs, accentuates that the case is sensitive and requires "de-politiciz[ing]" policies be adopted and implemented through a strategy to "build a modern army under KRG's authority" (Vatanka \& Shamsulddin, 2015). 
Associated with the above-mentioned challenges under the influence of the war against ISIS, Western states including the United States, the United Kingdom, and Germany decided in May 2017 to obligate themselves for a "multiyear plan" to modernize Peshmerga forces, giving the impression of being a precarious factor for the success of such strategy. In short, and as highlighted by $M$. Knights from the Washington Institute, compared with other forces in the Middle East region, the Peshmerga are among those that are more "professional and elite" (Gonzalez, 2015; Borsari, 2019). The above-visualized elaboration against all odds points to the fact that the above-mentioned powers recognize the position of the KRI as a security actor.

Therefore, as a challenge to Baghdad's policy in arming the KRI, the United States and NATO members were practically forced to look for a path to provide military armament to Peshmerga forces, something which Ashton Carter, Secretary of Defence, testified to the Senate Armed Services Committee on 7 July 2015 (CRS report, 2016). Historically, Kurds have attempted to gain their independent state and have fought with Iraq and other regional states. Therefore, the case of directly aiding Kurds, according to Senator Bob Corker, Chair of the Senate Foreign Relations Committee, is seemingly an action that supports the disintegration of Iraq and also the United States: "you are.... encouraging the breaking apart of the country" (Cook, 2016; Pace \& Lee, 2014). Thus, the United States should be careful. Having this in mind, according to data provided by the Congressional Research Service report published on 1 June 2016, the United States' reluctant approach to provide direct weapons to the KRI is connected to numerous factors, first, "minimizing Kurdish-Arab tensions in Mosul and Kurdish political control over ethnically mixed areas". Second, it is related to "Kurdish interests in maintaining control over the largely Kurdish-populated territory", and third, to "Improvement in non-Kurdish forces' capabilities via training, experience, and U.S. air and ground support" (CRS report, 2016). But others, such as Lt. Gen. William Mayville, the Director of Operations for the Joint Chiefs of Staff, believe that this is the task for the international coalition against ISIS. Meeting Kurdish demands and finding practical methods enable the KRI to fight a successful war against ISIS. Against all odds, the United States has not remained passive, but Kurds do not hide that they have received U.S. military support, with Psaki also acknowledging "we're providing those [to the KRI] - there's nothing new here" (Baldor \& Lee (2014).

On the other hand, such western direct engagements and political support for the KRI's Peshmerga might convey negative messages to Iraq and other regional powers. Also, in May 2017, the decision adopted by the United States, the United Kingdom, and Germany, in reality, was to put up "a national armed force" that might be associated with Kurdish statehood. Additionally, Peshmerga forces' close and intense relations with western military institutions and personnel necessitate having a clear stand regarding international law (Abdullah, 2017). Another perspective is the moral obligation for the casualties that the Peshmerga suffered in their war against ISIS. However, there is constant conflict between Iraq and the KRI on the status of the Peshmerga, but the UK has concluded that it "can probably argue with confidence that it would be legal to supply arms direct to the Kurdish Regional Government" (Smith et al., 2014). Admittedly, such a conclusion is based on an interpretation of the legal status of the Peshmerga forces within Iraq, with the UK perspective locating these forces into a category of "non-state actor", or a legal entity framed within the context of the Iraqi constitution. This means it is legal to supply such forces with weapons. The United States' supportive practice has changed in this regard due to the Public Laws 113-23512 (2015) and 113-291 (2015), which are good examples that have empowered different U.S. institutions to interact with the KRI regarding the arming process. This has involved both the Secretary of Defense and the Secretary of State to organize and manage a strategy not only to arm Iraqi forces but also include the KRI Peshmerga. Such an act goes further by referring to Iraqi non-state actors such as "tribal security forces or other local security forces" integrated within U.S. national security missions' objectives (Levin \& McKeon, 2014). In short, reading between different documents provided by Crispin Smith (2018, p. 257), there is a form of change in U.S. policy toward the KRI Peshmerga, one that empathizes the status of the latter as a military force. Further, House Resolution 1654 empowers the U.S. president to "only consult", which is different from asking for "consent" from Baghdad to arm the Peshmerga (Smith, 
2018). Therefore, these changes in the United States and its allies' approaches toward the KRI and its military subjects are crucial matters deserving of serious recognition, but it is also important to support the Peshmerga. In sum, such understanding creates a path toward political engagement with the KRI as a political authority for future cooperation.

\section{Conclusion}

As a society and political body, the KRI is a pro-western region where culture and the economy have progressed compared with other parts of Iraq (UK-Transcript of the doorstep interview with President Masoud Barzani, 31 Oct. 2005). The nature of Kurdish society is distinct from the rest of Iraq, and they do not hide their pro-American stance while also reflecting on the political self-governing nature to establish a better future. The 2003 Iraqi regime change, the Arab Spring, and the emergence of ISIS without a doubt have combined to construct new realities in the MENA. Apropos the KRI, in simple terms, such changes provide a mechanism for regional autonomy and power-sharing with the aim of conflict solving by and within states with a recognition of the KRI as a positive example to solve numerous minorities and ethnic-nations conflicts within the MENA region. Surely, active conflicts in progress, those without any hope of a political settlement, pose serious threats toward current nation-state structures and the balance of power structures in the region. In short, through such conflicts sub-state and other non-state actors have gained recognition.

Associated with the above-mentioned picture, at the beginning of the twenty-first century, new and novel opportunities arose regarding the Kurdish case, where a federal political structure created internationalization opportunities for the KRI. The last three decades of the KRI as a de facto or quasi-state have transformed the region into a parallel-sovereign state to Iraq when it comes to dealing with political and security issues within Iraq and also the surrounding nations. Second, the Syrian conflict made it possible for the United States and international coalitions to redesign their policy and shift towards an alliance with the newly raised Kurdish administration in North and East Syria, known as Rojava. Similar to the KRI and the Peshmerga, the Rojava Kurdish administration military forces (known as Syrian Democratic Forces) provided boots-on-the-ground assistance in the war against ISIS, thus becoming liable local partners for the United States. This environment has created a complex web of relations where a coalition of political and security objectives between regional states and superpowers (mainly the United States and Russia) has provided the Kurds, particularly in Iraq and Syria, with a golden opportunity to get more international attention and attempt to strengthen their position. For instance, the influence of ISIS on the internationalization of Kurdish case, even though regional states such as Turkey and Iran have differences but they are attempting to expand their economic and political ties with KRI.

The appearance of ISIS has seriously challenged the Iraqi military organization and its capabilities to resist. The nation is not willing to stand against such a terror organization to defend its national state border, accentuated by former President Barack Obama, who observed that Iraq was "not willing to stand and fight and defend their posts against admittedly hardened terrorists"( The White House, Statement by the President on Iraq, June 13, 2014). In this regard, the United States and its coalition partners' policy on arming Kurds has had wide complications, not only for the United States but particularly Turkey, which opposes the practice. By arming Kurds, the United States risks further alienating and further destabilizing its relations with its NATO ally Turkey. Also, this practice may empower the Kurds, but it also gives more feedstuff to the Adalet ve Kalknima Party (AKP) authoritarian regime to distance itself from the United States and seek to balance power against the nation, in this case by entering into relations with Russia and Iran, two of the United States' main adversaries in the region. Internationally, Kurds do not possess the same status as Turkey, which sheds light on the position each might have and the power they may be able to wield. Also, the United States' calculations should be focused on an awareness of the KRI and Kurds, as the United States may not be interested in endangering a key actor in its present geopolitical strategy.

The importance of Kurdish independence lies in the fact that Kurds find it impossible to be part of a state with other ethnic groups that are unwilling to accept others as equal citizens with the same rights. Visualizing Iraq's ethnosectarian nature, which is a product of the country's artificial nature, establishing security and instability requires both Baghdad and the KRI to accommodate realities within an 
overlooking period, with a focus on a foreseeable timetable to recognize the negative consequences of previous practiced policies, ones that have led Iraq into an ethno-sectarian divided society. Therefore, as a result of the referendum and a new post-referendum environment, Iraq would be best to accept the KRI as a reliable partner for further development. This would facilitate the establishment of a cooperative security mechanism on a broad range of issues. Therefore, in an article published in Washington Post former president of the KRI, Masoud Barzani accentuated now is the right moment for "the Kurdistan people to determine their future" Barzani, M., (2017). This should be a message not only to Iraq but also other regional actors, such as Iran and Turkey, to pressure Iraq further to resolve its conflict with Kurds. This would prevent further destabilization and a spill-over effect into their domestic Kurdish issues. From a security policy perspective, Iran and Turkey will gain much more by stabilizing the relationship between the KRI and Iraq than the current environment.

Apropos Iraq and its relations to the KRI, active and unsolved multi-dimensional subjects between the KRI and Baghdad are alarming and probably will have a spill-over effect. Additionally, Baghdad must avoid acting in a punitive manner toward the KRI, as doing so will exaggerate the cycle of conflict and will force the KRI to distance itself from Baghdad. This in turn might create further political instability in the country and increase regional actors' interference in Iraqi political issues, which could further damage Erbil-Baghdad relations. The behaviour of the Iraqi government and its lack of interest in implementing a constitution relating to the KRI's share of the budget, the disputed territory, and the military position of the Peshmerga, are subjects that further endanger the relationship. When ISIS appeared, the Iraqi government did not provide any support to the Kurds in their fight against terrorism and also blocked the international community from providing military assistant to the KRG in its fight against ISIS. On the other hand, the KRI Peshmerga forces are independent of the Iraqi government's political and military orders due to their constitution and legal rights according to the Iraqi constitution on legal security forces. This also seems to be a formula that western states within a coalition against ISIS adopted, placing importance on a new rule of engagement with the KRI's Peshmerga forces.

\section{REFERENCES}

Abdullah, D.(2017). International Coalition Supports Erbil to Unify, Develop Peshmerga. Retrieved May 8, 2017, from http://english.aawsat.com/d-abdullah/newsmiddle-east/international-coalitionsupportserbil-unify-develop-peshmerga.

Abdul-Zahra, Q. \& Kullab, S. (2020). Iraq officials: Rocket attack hits base housing US troops. Retrieved March 15, 2020, from https://abcnews.go.com/International/wireStor y/iraq-officials-rocket-attack-hits-basehousing-us-69594755

Ali, S. (2016). US Vice President-elect emphasizes Washington's support to Kurdistan. Retrieved Dec. 03, 2016, from https://www.kurdistan24.net/en/news/4c52f2cf -2b03-4362-beb4-036534e3c0a1/US-VicePresident-elect-emphasizes-Washingtonsupport-to-Kurdistan.

Aziz, S. (2019). The U.S.-Kurdish Relationship in Iraq After Syria. Washington Institute. Retrieved Dec. 3, 2019, from https://www.washingtoninstitute.org/fikraforu $\mathrm{m}$ /view/the-u.s.-kurdish-relationship-in-iraqafter-syria.

Baldor L.C., \& Lee, M. (2014). U.S. Sending Arms To Kurds In Iraq. Retrieved Agu, 11, 2014, from https://www.timesofisrael.com/ussending-arms-to-kurds-in-iraq/.

Barham Salih: The Issue Of Independent Kurdistan Could Not Be Accomplished Only Relied On Slogans. Retrieved June 1, 20115, from [Author Translation]. [Bahram Salih: Serbexoi Kurdistan Be Diroshimi Bikirdar Nakê]. Available

at: Http://Rudaw.Net/Sorani/Kurdistan/31052015 19. [ Accessed 01 June 2015].

Barton, N. (2018). To arm or not to arm the Kurds; a look at U.S. national security interests in Kurdistan. Pepperdine policy review, Vol. 10, Article 6.

Barzani, M., (2017). The time has come for Iraqi Kurdistan to make its choice on independence. Retrieved June 28, 2017, from https://www.washingtonpost.com/news/democ racy-post/wp/2017/06/28/the-time-has-comefor-iraqi-kurdistan-to-make-its-choice-onindependence/. [ Accessed, 30 June 2017].

Beaumont, P. (2020). Making of a martyr: how Qassem Suleimani was hunted down. Retrieved Jan. 5, 2020, from https://www.theguardian.com/world/2020/jan/ 05/making-of-a-martyr-how-qassemsuleimani-was-hunted-down. 
Government of Iraq [Jan 03, 2020]. Retrieved Jan 03, 3020 , from https://twitter.com/IraqiGovt/status/12130401 06115866626.

Bolton, J. (2019). May 30, 2019, Retrieved from https://twitter.com/AmbJohnBolton/status/113 4191782160470016?ref_src=twsrc\%5Etfw\% 7 Ctwcamp\%5Etweetembed\%7Ctwterm\%5E11 34191782160470016\&ref_url=https\%3A\%2F $\% 2$ Fwww.kurdistan24.net $\% 2$ Fen $\% 2$ Fnews $\% 2$ F08408bac-3f7f-44f9-9c04-2af58817d2c2.

Borsari, F. (2019). Institutionalization of the Peshmerga: tipping the balance of Iraq's stability. Middle East Research Institute (MERI). Policy Brief 16 July 2019. Vol. 4, No. 35 .

Britain says it is 'committed' to supporting Kurdish Peshmerga. Retrieved October 30-2019, from https://www.kurdistan24.net/en/news/00490be 2-912d-4e04-81a1-4ca00561173d.

Coggins III [Col. Myles B. Coggins III]. March 11, 2020. Retrieved from https://twitter.com/OIRSpox/status/123782357 3672239110.

Cavusoglu, M. (2019). Jun 10, 2019. Retrieved from https://twitter.com/MevlutCavusoglu/status/11 38012141070487552.

Cook, P. (2016) Department of Defense Press Briefing by Pentagon Press Secretary Peter Cook in the Pentagon Briefing Room. US Department of Defense. Retrieved Dec. 16, 2016, from https://www.defense.gov/Newsroom/Transcrip ts/Transcript/Article/1033978/department-ofdefense-press-briefing-by-pentagon-presssecretary-peter-cook-in/.

Cordesman, A. H. (2015). Iraqi stability and the ISIS war. Center for strategic \& international studies. Retrieved Feb. 15, 2016, from https://www.csis.org/analysis/iraqi-stabilityand-isis-war.

Cornago, N. (1999). Diplomacy and paradiplomacy in the redefinition of international security: Dimensions of conflict and co-operation. Regional \& Federal Studies, 9:1, 40-57.

CRS report (2016) Kurds in Iraq and Syria: U.S. Partners Against the Islamic State. Congressional Research Service. Pp. 1-21. P. 4. Retrieved June. 1, 2016 from https://crsreports.congress.gov/product/pdf/R/ R44513/7.

CRS report (2016) Kurds in Iraq and Syria: U.S. Partners Against the Islamic State. Congressional Research Service. Pp. 1-21. P. 4. Retrieved June. 1, 2016, from https://crsreports.congress.gov/product/pdf/R/ R44513/7.
Dalay, G. (2015). Regional Kurdish politics in the post-ISIS period. Retrieved Feb 11, 2015, from, https://studies.aljazeera.net/ar/node/1393.

Dalay, G. (2016). Kurdish Politics amid the fight against ISIS can a common cause surmount old rivalries? Retrieved Feb 11, 2015, from https://studies.aljazeera.net/en/reports/2016/02 /201627855330580.html.

Entessar, N. (2009). The Kurdish Factor In Iran-Iraq Relations. Retrieved Jan. 19, 2009, from https://www.mei.edu/publications/kurdishfactor-iran-iraq-relations.

FM Zarif Congratulates Barzani on Election as KRG President. Islamic Republic of Iran Ministry of Foreign affairs. Retrieved May 30, 2019, from https://en.mfa.ir/portal/newsview/37405.[ accessed, May, 30, 2019].

Frantzman, S.J. (2019). The Kurdistan Region of Iraq Is Struggling to Survive. Retrieved Oct. 21, 2019, from https://nationalinterest.org/feature/kurdistanregion-iraq-struggling-survive-90021.

Gonzalez, E. (2015). Kurdish Peshmerga: Divided From Within. Retrieved Sep. 5, 2015, from http://Harvardpolitics.Com/World/KurdishPeshmerga-Divided-Within/.

Gould ‘, J., et. Al. (2017). Pentagon says Iraqi trainand-equip mission could end if attacks on Kurds continue. Retrieved Oct. 16, 2017, from https://www.defensenews.com/congress/2017/ 10/16/baghdad-retakes-kirkuk-and-pentagonmulls-ending-train-and-equip/.

Hunt, J., (2019). Maj 29, 2019. Retrieved from https://twitter.com/Jeremy_Hunt/status/11337 31711517364226.

Ibrahim, A. (2020). Iraqi parliament calls for the expulsion of foreign troops. Retrieved Jan 05, 2020 from https://www.aljazeera.com/news/2020/01/iraqi -parliament-calls-expulsion-foreign-troops200105150709628.html.

Ignatius, D. (2016). The new coalition to destroy the Islamic state. Retrieved May 22, 2016, from https://www.washingtonpost.com/opinions/the -new-coalition-to-destroy-the-islamicstate/2016/05/22/54d9b466-2036-11e6-aa8442391ba52c91_story.html.

International Crisis Group (2019). After Iraqi Kurdistan`s thwarted independence bid. Retrieved Nov.12, 2020, from https://www.crisisgroup.org/middle-eastnorth-africa/gulf-and-arabianpeninsula/iraq/199-after-iraqi-kurdistansthwarted-independence-bid.

Iranian Parliament Speaker: All Parties In Kurdistan Are Our Allies. Retrieved Dec. 27, 2014, from Http://Www.Basnews.Com/En/News/2014/12/ 
27/Iranian-Parliament-Speaker-All-In-

Kurdistan-Are-Our-Allies-And-Friends/.

27.12.2014.

Iraq protests: All the latest updates. Retrieved Oct 11,

2019 ,

from

https://www.aljazeera.com/news/2019/10/iraq-

protests-latest-updates-

191004085506824.html.

Iraq refuses talks with Kurds about referendum results. Retrieved Sep. 26, 2017, from https://www.aljazeera.com/news/2017/09/iraqrefuses-talks-kurds-referendum-results170926033646791.html.

Iraq unrest: Protesters set fire to the Iranian consulate in Najaf. Retrieved Nov 28, 2019, from https://www.bbc.com/news/world-middleeast-50580940.

Iraqi Kurdistan PM in Iran for talks. Retrieved 06 June 2014, from ttps://ekurd.net/mismas/articles/misc2014/6/st ate8091.htm.

Iraq's Constitution of 2005. Retrieved Dec. 20, 2020, from

https://www.constituteproject.org/constitution/ Iraq_2005.pdf?lang=en.

Iraq's Shiites helped boost the political elite in Baghdad now they want to bring it down. Retrieved Dec. 28, 2019, from https://www.washingtonpost.com/world/middl e_east/iraqs-shiites-helped-boost-the-politicalelite-in-baghdad-now-they-want-to-bring-itdown/2019/12/28/7768d0e0-20da-11ea-b034de7dc2b5199b_story.html.

Kent, G. (2015). Prospects For A Future Kurdistan. Retrieved June 20, 2015, from https://www.opendemocracy.net/en/northafrica-west-asia/prospects-for-futurekurdistan/ .

Kurds To Kerry: We Are Facing A 'New Iraq'. Retrieved June 24, 2014, from https://meo.news/en/kurds-kerry-we-arefacing-new-iraq.

Lee, J. (2019). PM Condemns Killing of Qasem Soleimani. Retrieved Jan 3, 2019, from https://www.iraq-

businessnews.com/2020/01/03/pm-condemnskilling-of-qasem-soleimani/.

Levin, C. \& McKeon, H.P.B. (2014). National Defense Authorization Act for Fiscal Year 2015. Public Law 113-291-Dec. 19, 2014. Retrieved from https://www.congress.gov/113/plaws/publ291/ PLAW-113publ291.pdf.

Martin, P., \& Kozak, Ch. (2016). The pitfalls of relying on Kurdish forces to counter ISIS. Institute for the study of war (ISW). Retrieved Feb, 03, 2016, from: https://www.files.ethz.ch/isn/195947/The\%20
Pitfalls\%20of\%20Relying\%20on\%20Kurdish $\% 20$ Forces\%20to\%20Counter\%20ISIS.pdf .

Mustafa, H. (2020). Kurdish-Shiite Dispute over US Troops Ends their 'Historic Alliance' in Iraq. Retrieved Jan 18, 2020, from https://aawsat.com/English/home/article/2088 461/Kurdish-shiite-dispute-over-us-troopsends-their-'historic-alliance'-iraq.

Nechirvan Barzani was elected president of Iraq's Kurdish region. Retrieved May 28, 2019, from https://www.aljazeera.com/news/2019/05/nech irvan-barzani-elected-president-iraq-kurdishregion-190528101712570.html

O'Leary, B. (2017). The Kurds, the four wolves, and the great powers. Journal of politics, 1-14. Queen`s University Belfast- Ireland. http://doi.org/10.1086/695343.

Pace, J \& Lee, M. (2014). The U.S. Begins Arming Iraq's Kurds Against Islamic State. Retrieved Aug 11, 2014, from https://www.haaretz.com/u-s-arming-iraq-skurds-against-islamic-state-1.5258937.

Panel 7: Turmoil and Disorder - A New Sykes-Picot? Sulaimani forum 2016. American University in Sulaimani. Retrieved May 25, 2016, from https://auis.edu.krd/sulaimaniforum2016/panel $-7$.

Park et.al. (2017). On the independence referendum in the Kurdistan Region of Iraq and disputed territories in 2017. Kurdish Studies, Vol: 5, No: 2, pp. $199-214$.

Pollack, K.M. (2015). Iraq after the fall of Ramadi: How to avoid another unraveling of Iraq. Retrieved May 22, 2015, from https://www.brookings.edu/blog/markaz/2015/ 05/22/iraq-after-the-fall-of-ramadi-how-toavoid-another-unraveling-of-iraq/.

Pollock, D.(2020). Iraq's Kurds Weigh Their Options, Balancing the United States and Iran. Retrieved March 20, 2019, from https://www.washingtoninstitute.org/fikraforu $\mathrm{m}$ /view/iraqs-kurds-weigh-their-options.

President Macron in meeting with PM Barzani sets terms of the Erbil-Baghdad dialogue. Retrieved Dec.02, 2017, from https://www.rudaw.net/english/kurdistan/0212 20171.

Readout of Vice President Mike Pence's Call with Iraqi Kurdistan Region President Nechirvan Barzani. Retrieved Aug. 27, 2019, from https://www.whitehouse.gov/briefingsstatements/readout-vice-president-mikepences-call-iraqi-kurdistan-region-presidentnechirvan-barzani/.

Saeed, Y. (2015). US: no direct arms deliveries to Iraqi Kurds. Retrieved Feb. 10, 2015, from http://rudaw.net/english/kurdistan/100220151. 10/2/2015. 
Sinkaya. B. (2015). Iran-KRG Relations Within The Grip Of Distrust. Retrieved 14 July 2015, from http://Www.Orsam.Org.Tr/En/Article_Print.A spx? ID $=2853$.

Smith, B. et al., (2014). UK arms transfer to the Peshmerga in Iraqi Kurdistan. The U.K. Retrieved Aug. 18, 2014, from https://commonslibrary.parliament.uk/research -briefings/sn06963/.

Smith, C. (2018). Independent Without Independence: The Iraqi-Kurdish Peshmerga in International Law. Harvard International Law Journal. Vol. 59, No. 1, 2018. Retrieved from https://ssrn.com/abstract=3003644.

The White House, Statement by the President on Iraq. Retrieved June 13, 2014, from https://obamawhitehouse.archives.gov/thepress-office/2014/06/13/statement-presidentiraq.

U.S. Department of State (2019). Department Press Briefing-May 28, 2019. Retrieved May 28, 2019, from https://www.state.gov/briefings/departmentpress-briefing-may-28-2019/. [accessed, May, 29, 2019].

U.S. Department of State (2020). State Secretary Michael R. Pompeo's Call with Kurdistan Regional Government Prime Minister Masrour Barzani. Retrieved Jan 7, 2020, from https://www.state.gov/secretary-michael-rpompeos-call-with-kurdistan-regionalgovernment-prime-minister-masrour-barzani/.

UK Gifts Arms and Ammunition to Kurdish Regional Government. Retrieved Sept. 9, 2014from https://www.defense-aerospace.com/articlesview/release/3/156884/uk-gifts-arms-tokurdish-regional-government.html.
UK Prime Minister (2019). Maj 29, 2019. Retrieved from https://twitter.com/10DowningStreet/status/11 33755533381513216. [accessed, Maj 29, 2019].

UK-Transcript of the doorstep interview with President Masoud Barzani. Retrieved 31 Oct. 2005 ,

from http://previous.cabinet.gov.krd/a/d.aspx?l=12 $\&$ smap $=010000 \& a=7175$.

Vatanka, A., \& Shamsulddin, S. (2015). Forget ISIS: Shia Militias Are the Real Threat to Kurdistan. Retrieved Jan. 17, 2015, from http://nationalinterest.org/feature/forget-isisshia-militias-are-the-real-threat-kurdistan11982 ?page $=2$.

Warr, M., (2019). Maj 29, 2019. Retrieved from https://twitter.com/WarrMartyn/status/113374 4915777769472. [accessed, Maj 29, 2019].

Wintour, P., (2017). Anti-ISIS coalition risks descending into war before caliphate crushed. Retrieved Oct. 16, 2017, from https://www.theguardian.com/world/2017/oct/ 16/fears-of-new-guerrilla-war-before-isisdream-of-caliphate-is-crushed.

Zaman, A. (2020). Iraq's Kurds weigh opportunities, risks in wake of Soleimani killing. Retrieved Jan. 7, 2020, from https://www.almonitor.com/pulse/originals/2020/01/iraqkurds-opportunity-risk-soleimani-killing-iraqtensions.html.

Zucchino, D., (2016) Iraqi Forces Sweep Into Kirkuk, Checking Kurdish Independence Drive. Retrieved Oct. 16, 2017, from https://www.nytimes.com/2017/10/16/world/m iddleeast/kirkuk-iraq-kurds.html. 
يوخته

كَشهدانيّن داوى ييّين ل رِوزَهلاتا ناقين و ئافريكايا باكور (مهنا)، وهكى بهارا ئهرهبى و دهركهتنا دا

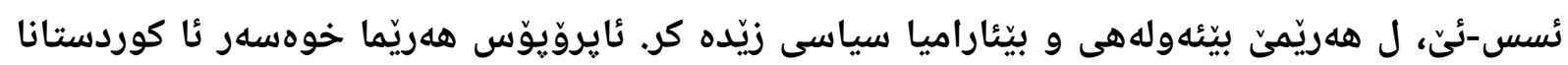

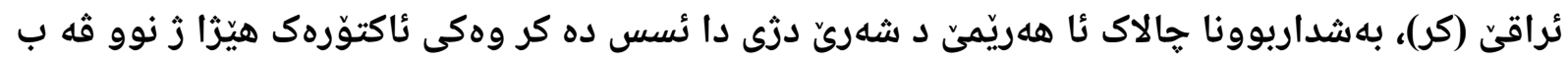

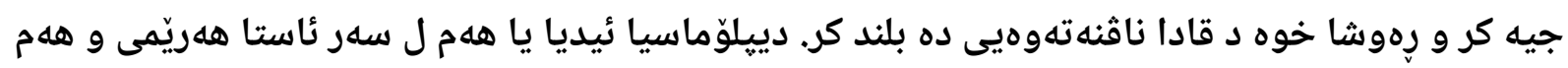

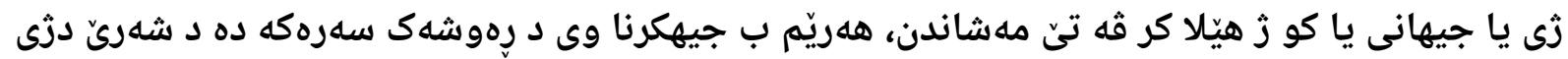

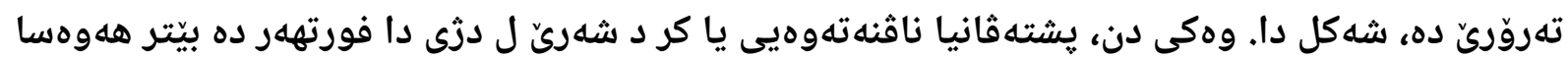

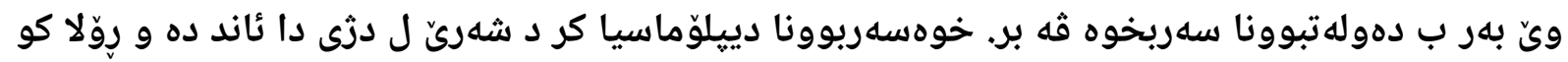

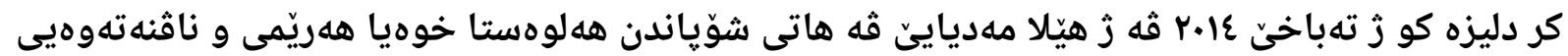

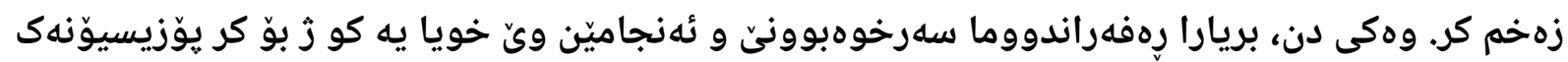

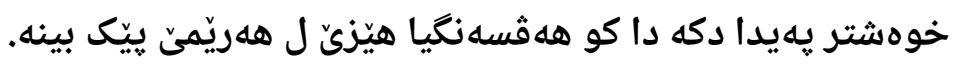

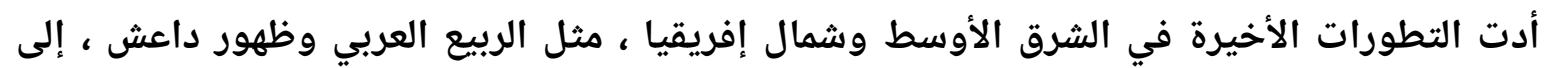

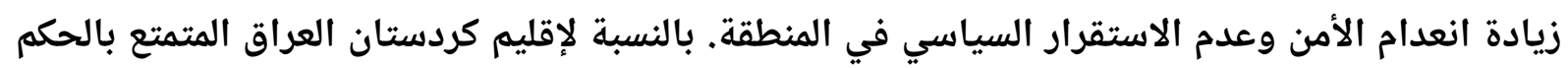
الذاتي ، فقد أدت المشاركة النشطة للمنطقة في الحرب ضد ادها داعش إلى إعادة وضع إقليم كردستان العراق

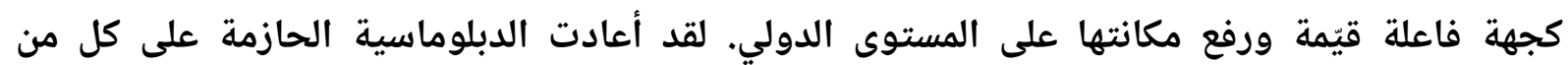
المسرحين الإقليمي والعالمي التي مارسها إقليم كوردستان العراق تشكيل المنطقة من خلال وضعها في موقع رئيسي في الحرب على الإرهاب. علاوة على ذلك ، أدى الدعم الدولي لإقليم كوردستان في حربه ضد فال

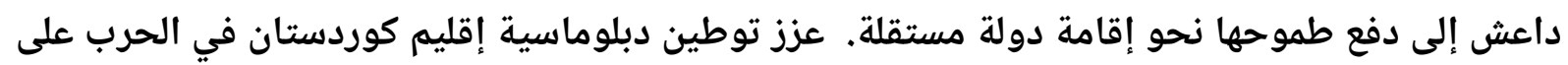

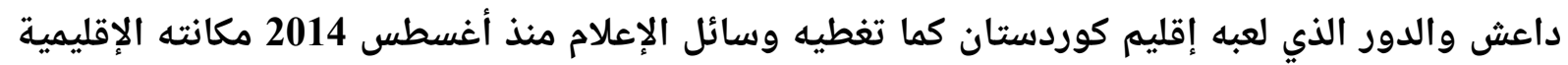
والدولية. علاوة على ذلك ، يبدو أن قرار استفتاء الاستقلال ونتائجه قد وفّر موقفًا أكثر راحة لإقليم

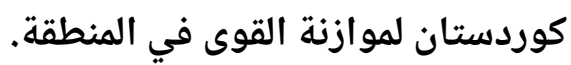

